\title{
Essay
}

\section{Social Entrepreneurship: Perspectives on an Academic Discipline}

\author{
Karen Braun ${ }^{1}$
}

The concept of social entrepreneurship has become increasingly popular in the discourse of academic departments. This paper explores several aspects of social entrepreneurship and the questions that arise when attempting to place the field within one discipline. Connections are made to the potential contribution of a transdisciplinary approach to the scholarly inquiry of social entrepreneurship. It concludes by suggesting that transdisciplinarity may result in greater accuracy in the data collected. [Article copies available for a fee from The Transformative Studies Institute. E-mail address: journal@transformativestudies.org Website: http://www.transformativestudies.org (C2009 by The Transformative Studies Institute. All rights reserved.]

KEYWORDS: Social Entrepreneurship, Transdisciplinary Studies, Social Change, Academic Studies.

When I engage in conversations with colleagues who are interested in social entrepreneurship and who are trying to develop a more succinct definition of the field and its relationship to education, there is always a sense of a mixed excitement and frustration. Being part of developing a 'new' field in the academic institution is a rewarding challenge that comes with much uncertainty as it does conviction.

In this article, I will briefly define social entrepreneurship and discuss the place it presently has in higher education. I will than explore the potential of transdisciplinary inquiry as a possible approach to effectively research and gather accurate data in the field of social entrepreneurship.

\footnotetext{
${ }^{1}$ Karen Braun is a Ph.D. student in Transformative Studies at the California Institute of Integral Studies. Her area of interest is social entrepreneurship and education. Karen Braun has been a teacher for seven years and completed her Masters of Global Education at the University of Toronto. Address correspondence to: Karen Braun, 130 Briarcliffe Crescent, Waterloo, Ontario, Canada N2L 5T8; tel: 519-502-6047; e-mail: kbraun77@gmail.com.
} 